доцент кафедри Економічного аналізу та обліку tattilija@gmail.com

ORCID 0000-0001-6544-7602

Національний технічний університет «Харківський політехнічний інститут», Харків, Україна

\title{
ОБЛІКОВО-АНАЛІТИЧНЕ ЗАБЕЗПЕЧЕННЯ УПРАВЛІННЯ НЕМАТЕРІАЛЬНИМИ АКТИВАМИ В КОНТЕКСТІ ІННОВАЦИЙНОГО РОЗВИТКУ ЗАЛІЗНИЧНОГО ТРАНСПОРТУ
}

Анотація. В статті визначена необхідність інноваційного розвитку залізничного транспорту Украӥни та його залежність від організаиії ефективного управління нематеріальними активами АT «Укрзалізниия». Виявлено проблемні питання в сфері управління нематеріальними активами $A T$ «Укрзалізниия» та акцентовано увагу на доцільності створення системи управління нематеріальними активами, щуо підпорядковується стратегії інноваційного розвитку залізничного транспорту та підсистемами якої є: управління НДДКР і технічними інноваціями, управління інноваційним потенщіалом і розвитком персоналу, управління організачійною взаємодією та координацією заходів, управління внутрішньою та зовнішньою інформацією та комунікаціями тощо. Визначено, щчо управління нематеріальними активали залізничного транспорту потребує підвищення якості облікової інформащї, а саме: здійснення переоцінки наявних нематеріальних активів АT «Укрзалізниия» та ї̈ підприємств за справедливою вартістю;введення практики оприлюднення додаткових звітів щодо нематеріальних активів AT «Укрзалізниия» та його підприємств. Визначено доиільність оприлюднення Консолідованого звіту про інтелектуальний капітал $A T$ «Укрзалізниця» та його дочірніх підприємств, який дозволить внутрішнім та зовнішнім користувачам інформації за допомогою фінансових і нефінансових показників та індикаторів отримати дані про стан інтелектуально-інноваційного розвитку залізничного транспорту як складного виробничо-технологічного комплексу, підвищити прозорість звітності, а керівництву АT «Укрзалізниця» інтегрувати фінансову та інноваційно-інвестиційну стратегії розвитку компанії.

Ключові слова: нематеріальний актив, управління, розвиток, система, облікова інформачія, обліково-аналітичне забезпечення.

() Якименко-Терещенко Н.В., Жадан Т.А., 2019

УДК 657.421.3

JEL Classification: M 40, M 10

DOI 10.31375/2226-1915-2019-3-86-96
Н.В. Якименко-Терещенко д.э.н., профессор, заведующий кафедрой Экономического анализа и учета mtkgd@ukr.net

ORCID 0000-0003-2927-7989

Т.А. Жадан к.э.наук, доцент, доцент кафедры Экономического анализа и учета tattilija@gmail.com ORCID 0000-0001-6544-7602

Национальный технический университет «Харьковский политехнический институт», Харьков, Украина 


\title{
УЧЕТНО-АНАЛИТИЧЕСКОЕ ОБЕСПЕЧЕНИЕ УПРАВЛЕНИЯ НЕМАТЕРИАЛЬНЫМИ АКТИВАМИ В КОНТЕКСТЕ ИННОВАЦИОННОГО РАЗВИТИЯ ЖЕЛЕЗНОДОРОЖНОГО ТРАНСПОРТА
}

Аннотация. В статье определена необходимость инновационного развития железнодорожного транспорта Украины и его зависимость от организации

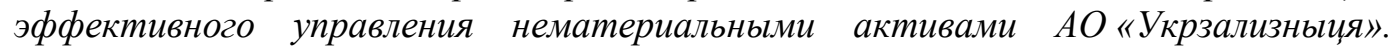
Выявлены проблемные вопросы в сфере управления нематериальными активами АО «Укрзализныця» и акцентировано внимание на иелесообразности создания системы управления нематериальными активами, которая подчиняется стратегии инновационного развития железнодорожного транспорта и подсистемами которой являются: управление НИОКР и техническими инновачиями, управление инновационным потенциалом и развитием персонала, управление организачионным взаимодействием и координачией мероприятий, управление внутренней и внешней информацией и коммуникачиями и т.д. Определено, что управление нематериальными активами железнодорожного транспорта требует повышения качества учетной информации, а именно: осуществление переоценки

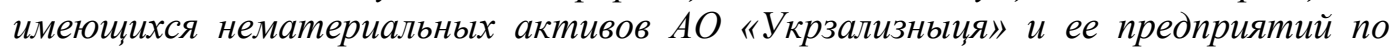
справедливой стоимости, введение практики обнародования дополнительных отчетов по нематериальным активам АO «Укрзализныця» и его предприятий. Определена иелесообразность обнародования консолидированного отчета об интеллектуальном капитале $А O$ «Укрзализныия» и его дочерних предприятий, который позволит внутренним и внешним пользователям информации с помощью финансовых и нефинансовых показателей и индикаторов получить данные о состоянии интеллектуально-инновачионного развития железнодорожного транспорта как сложного производственно-технологического комплекса, повысить прозрачность отчетности, а руководству $A O$ «Укрзализныия» интегрировать финансовую и инновационно-инвестищионную стратегии развития компании.

Ключевые слова: нематериальный актив, управление, развитие, система, учетная информачия, учетно-аналитическое обеспечение.

UDC 657.421.3

JEL Classification: M 40, M 10

DOI 10.31375/2226-1915-2019-3-86-96
N.V. Yakymenko-Tereschenko Doctor of Economics, Professor, Head of the Department of economic analysis and recording mtk_gd@ukr.net

ORCID 0000-0003-2927-7989

T.A. Zhadan

PhD. InEconomics, Assistant Professor, Assistant professor at the Department of economic analysis and recording tattilija@gmail.com

ORCID 0000-0001-6544-7602

National Technical University

«Kharkiv Polytechnic Institute», Kharkiv, Ukraine

\section{ACCOUNTING AND ANALYTICAL SOFTWARE FOR NON-TANGIBLE ASSETS MANAGEMENT IN TERMS OF RAILWAY TRANSPORT INNOVATIVE DEVELOPMENT}

\begin{abstract}
The article specifies the necessity of railway transport innovative development in Ukraine and its dependency on efficient management over non-tangible assets of Joint Stock Company "Ukrzalizhytsa». There are disputed issues in terms of management over non-tangible assets of Joint Stock Company «Ukrzaliznytsya» and the reasonability of creating the non-tangible assets management system to be subordinated to railway transport innovative development strategy is on the first place, its subsystem
\end{abstract}


consists of: scientific research and development and technical innovation management, innovative potential and personnel development management, cooperation and measure coordination management, external and internal information and communication management, rights portfolio and intellectual rights management, commercialization and evaluation management. It specifies that railway transport non-tangible assets management requires improved quality of accounting information, in particular: re-evaluation of current non-tangible assets of Joint Stock Company "Ukrzaliznytsya» and its enterprises at fair cost; implementation of the practice of publishing additional reports on non-tangible assets of Joint Stock Company «Ukrzaliznytsya» and its enterprises, that, firstly, give detailed information on non-tangible assets specified in financial reporting, reflect sectoral specification and include both financial and non-financial figures; secondly, integrate information on non-tangible assets specified in financial reporting and include a set of additional financial figures or indicators. The reasonability of publishing the consolidated report on intellectual capital of Joint Stock Company "Ukrzaliznytsya» and its subsidiaries has been specified, thus, based on financial and non-financial figures and indicators, enabling inner and external information users to receive information on railway transport intellectual and innovative development as comprehensive production and technological complex, to increase reporting transparency, and the management of Joint Stock Company «Ukrzaliznytsya» will be able to integrate financial, innovative and investment strategy of company development.

Keywords: non-tangible asset, management, development, system, accounting information, accounting and analytical software.

Постановка проблеми. За даними Держкомстату України, що проводив дослідження за європейською методологією CIS (Community Innovation Survey), частка інноваційно-активних підприємств транспорту складає лише 7,3 \%. Серед проблем, 3 якими стикаються підприємства транспорту, нестача як власних, так і залучених фінансових ресурсів, недостатня підтримка держави та недосконалість законодавчої бази, відсутність фундаментальних та не-стача прикладних наукових дослід-жень у галузі, низький попит на інновації, значна ризикованість та тривалі терміни окупності інновацій. Незначний обсяг інвестицій в транспортну галузь (біля $10 \%$ загального обсягу інвестицій по країні) стало причиною системних та масштабних проблем, у тому числі на залізничному транспорті. Так за даними АТ «Укрзалізниця» (UZ), рівень інвестицій в активи порівняно з іншими операторами у чотири рази менший середнього значення (рис. 1). Фактичний рівень капітальних вкладень у 2017 році порівняно
32011 роком скоротився майже на 80 \%. Планом капітальних інвестицій на 2018 рік по АТ «Укрзалізниця» їх обсяг мав скласти 36,2 млрд. грн., у тому числі: на придбання (виготовлення) рухомого складу - 15,3 млрд. грн., модернізацію - 8,1 млрд. грн., придбання (створення) нематеріальних активів - 0,3 млрд. грн., придбання інших основних засобів (машин, механізмів та обладнання) - 1,9 млрд. грн., капітальне будівництво - 6,9 млрд. грн., капітальний ремонт - 3,1 млрд. грн.

Недостатній обсяг інвестицій в залізничний транспорт, у першу чергу в його інноваційний розвиток, стало причиною критичного зносу основних засобів: магістральні колії 3 простроченим капітальним ремонтом складають 27 \% від загальної протяжності, колійна техніка 3 понад нормативним терміном служби складає $78 \%$ від загальної кількості, знос тягових підстанцій складає $67 \%$, а контактної мережі - 55 \%; зношеність парку магістральних електровозів $84 \%$, магістральних тепловозів - 
$99 \%$, маневрових тепловозів - понад $80 \%$; зношеність парку вантажних вагонів - понад $90 \%$, пасажирських вагонів - $87 \%$, електро- і дизельпоїздів - близько $90 \%$.

Складність ситуації вимагає від керівництва залізничного транспорту невідкладних дій. Розроблена «Стратегія розвитку АТ «Укрзалізниця» на 2017-2021 роки» (Стратегія), реалізація якої потребує капітальних інвестицій у розмірі 148,5 млрд. грн. За п’ятьма вертикалями (вантажних перевезень та логістики, інфраструктури, пасажирських перевезень, послуг тяги, виробництва та сервісу), Стратегія включає такі стратегічні ініціативи:

- оптимізація парку локомотивів для забезпечення прогнозованих обсягів перевезень: придбання нового тягового рухомого складу та модернізація (біля 30 \% магістральних локомотивів);

- підвищення продуктивності залізничної інфраструктури (будівництво, електрифікація, реконструкція);

- придбання нового рухомого складу - розширення мережі швидкісних поїздів IC, IC+, Нічний експрес;

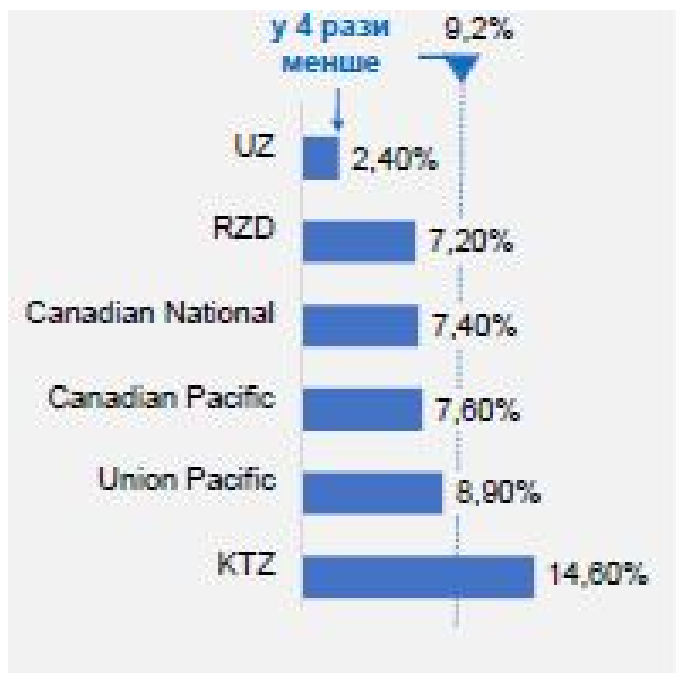

Рис. 1. Рівень капітальних вкладень у 2017 р., \%

- оптимізація системи ремонту рухомого складу (економія 5-20\% по різних статтях витрат);

- залучення інвесторів та формування стратегічних партнерств зі світовими лідерами 3 виробництва та модернізації тягового рухомого складу тощо.

Таким чином, нині спостерігається невідповідність залізничного транспорту в частині інфраструктури, якості тягового рухомого складу, обладнання, спектру і якості сервісних послуг стандартам, директивам, регламентам, нормам і вимогам Європейського Союзу, а тому його роз- виток має будуватися на інноваційній основі.

Ключовим ресурсом інноваційного розвитку залізничного транспорту є нематеріальні активи (HМА).

Огляд останніх досліджень і публікацій. Важлива роль у науковому доробку щодо управління нематеріальними активами суб'єктів господарювання належить таким вітчизняним науковцям як С.А. Бондаренко, I.О. Борисюк, А.А. Пилипенко та ін. [1-3]. Крім того, питанням удосконалення обліково-аналітичного забезпечення управління нематеріальними активами присвячені останні 
наукові дослідження В.М. Диби, I.M. Дрогобицького, П.О. Куцик, I.C. Старко, В.С. Шелест та ін. [4-7]. Оскільки роль нематеріальних активів в процесах розвитку залізничного транспорту зростає, потребує більш глибокого наукового дослідження проблеми створення ефективної системи управління нематеріальними активами АТ «Укрзалізниця».

Задачі дослідження. Метою статті $€$ визначення залежності інноваційного розвитку залізничного транспорту України від ефективності управління нематеріальними активами та внесення рекомендацій щодо напрямів підвищення якості облікової інформації при створенні ефективної системи управління нематеріальними активами АТ «Укрзалізниця».

Основний матеріал дослідження. Норми, що стосуються НМА (у тому числі інтелектуальної власності), містяться у багатьох законах України [8-10]. Це, зокрема, Господарський, Податковий i Цивільний кодекси України, закони «Про охорону прав на винаходи i корисні моделі», «Про охорону прав на промислові зразки», «Про охорону прав на знаки для товарів і послуг» та інші. Поняття НMA є багатогранним. Відповідно до бухгалтерського підходу до змісту поняття НMA саме майнове право є об'єктом обліку НMА і облікові процедури (оцінка, переоцінка, нарахування амортизації, зменшення, збільшення корисності) проводяться саме 3 ним. Національне положення стандарт) бухгалтерського обліку в державному секторі 122 «Нематеріальні активи» встановлює, що НМА визнається активом, якщо його можна ідентифікувати (може бути виділений чи відокремлений від інших активів) та існує ймовірність отримання суб' $€$ ктом державного сектору майбутніх економічних вигід, пов'язаних з його використанням, та/ або якщо він має потенціал корисності і його вартість може бути достовірно визначена. Для цілей бухгалтерського обліку НМА включають: авторське та суміжні 3 ним права, права користування природними ресурсами, права на знаки для товарів і послуг, права користування майном, права на об'єкти промислової власності, інші нематеріальні активи.

НМА значною мірою є джерелами більшості технологічних, технічних i продуктових нововведень, що обумовлюється функціями, які вони виконують:

- технічна - насичення продукту особливими споживчими властивостями;

- технологічна - забезпечення технологічної переваги над конкурентами;

- правова - забезпечення високого та стабільного захисту бізнесу;

- економічна - управління кругообігом інтелектуального капіталу 3 метою стабільного отримання надприбутків та нарощування його вартості та інноваційного потенціалу;

- соціальна - ідентифікація бізнесу у свідомості споживача на основі бренд-стратегії;

- психологічна - формування індивідуальної та масової корпоративної культури у конкретному бізнес-середовищі [4].

Актуальним для залізничного транспорту як складного виробничотехнологічного комплексу $є$ формування системи управління НМА.

Управління НMA - це сукуність дій і заходів, спрямованих на забезпечення ефективного планування, організації та контролю процесів формування, розвитку і використання інтелектуальних активів під-приємства, а також мотивації про- цесів накопичення і примноження НМА.

Нині аналіз управління НМА AT «Укрзалізниця» підтверджує наявність проблемних питань в сфері: визначення вартості HМА, управління їх портфелем; формування та ефективного застосування організаційно-еко- 
номічних механізмів створення, використання і комерціалізації НМА; визначення основних напрямів політики компанії в області створення і використання НМА; здійснення прогнозування потреби в нових видах НМА; проведення аналізу ефективності створення і використання НMA; формування нормативів внутрішнього управління НМА. Процес управління НМА повинен бути системним і підкорятися інноваційним цілям $[1 ; 11]$. Система управління НMA має бути підпорядкована стратегії інноваційного розвитку залізничного транспорту, при цьому інтегрувати в загальну систему управління. Підсистемами управління НМА АТ «Укрзаліз-ниця» мають бути:

ними інноваціями;

- управління НДДКР і техніч-

- управління інноваційним

потенціалом і розвитком персоналу;

- управління організаційною взаємодією та координацією заходів;

- управління внутрішньою інформацією та комунікаціями;

- управління зовнішньою інформацією та комунікаціями;

- управління портфелем прав на об'єкти інтелектуальної власності;

- управління комерціалізацією та оціночною діяльністю.

Як зазначає, В. Семчик, використання інтелектуальної власності в якості нематеріальних активів у господарській діяльності АТ «Укрзалізниця〉 та його підприємств, а також відображення в бухгалтерському обліку операцій з використання таких об'єктів, має сприяти [12]:

- документальному підтвердженню довгострокових майнових прав на підставі їх обліку на балансі підприємства;

- здійсненню амортизації нематеріальних активів у встановленому порядку залежно від терміну їх корисного використання, що дозволяє отримати амортизаційні фонди для подальшого оновлення нематеріаль- них активів;

- отриманню додаткових прибутків від передачі прав використання об'єктів інтелектуальної власності, а також забезпеченню обгрунтованого регулювання цін на інноваційну продукцію підприємства;

- налагодженій сплаті фізикним та юридичним особам авторської винагороди у формі роялті (паушальних платежів, одноразової авторської винагороди тощо);

- здійсненню комерційних операцій застави, обміну на надійні активи, реалізації тощо з метою отримання доходів і залучення відповідних кредитних ресурсів;

- оновленню технічного стану виробництва i технологій шляхом впровадження інтелектуального капіталу в господарський оборот підприємств;

- здійсненню корпоративних (трансакційних) операцій шляхом внесення до статутних капіталів інших підприємств (господарських товариств) власного інтелектуального продукту, що дозволяе залучити додатково фінансові ресурси й отримати відповідні корпоративні права 3 метою впливу на діяльність господарських товариств.

Управління НMA залізничного транспорту в контексті забезпечення інноваційного розвитку потребує підвищення якості облікової інформації, а саме:

1) здійснення переоцінки наявних нематеріальних активів АТ «Укрзалізниця» та іiі підприємств за справедливою вартістю;

2) введення практики оприлюднення додаткових звітів щодо нематеріальних активів АТ «Укрзалізниця» та його підприємств. Серед таких звітів можуть бути звіти, які:

- деталізують інформацію про нематеріальні активи, розкриті в фінансовій звітності, відбивають галузеву специфіку та включають як 
фінансові, так і не фінансові показники;

- доповнюють інформацію про нематеріальні активи, розкриті в фінансовій звітності, що важливо для підвищення рівня об'єктивності аналізу діяльності АТ «Укрзалізниця» та його підприємств, та містять набір нефінансових показників;

- інтегрують інформацію про нематеріальні активи, яка розкрита в фінансовій звітності, та включають набір додаткових фінансових показників або індикаторів («Звіт про інтелектуальний капітал»).

Відповідно до Рекомендацій 3 управління та звітування про нематеріальні активи: звіт про інтелекттуальний капітал, які розроблені в межах проекту «MERITUM», управління інтелектуальним капіталом (людським, структурним та капіталом відносин) має здійснюватися у такій послідовності: ідентифікація НMA, вимірювання НМА, консолідація та інтеграція НМА з управлінськими моделями. На кінцевій фазі управ-ління має бути створений Звіт про інтелектуальний капітал, який відображує стратегічні цілі компанії та іiі ключові НМА, анотований огляд HMA і систему індикаторів НMA та видів діяльності компанії. Перевагою оприлюднення Консолідованого звіту про інтелектуальний капітал АТ «Укрзалізниця» та його дочірніх підприємств (ПрАТ «Дніпропетровський тепловозоремонтний завод», ПрАТ
«Запорізький електровозоремонтний завод», ПрАТ «Львівський локомотиворемонтний завод», ПрАТ «Київський електровагоноремонтний завод», ПрАТ «Коростенський завод залізобетонних шпал», ПрАТ «Гніванський завод спецзалізобетону», ПрАТ «Київський електротехнічний завод «Транссигнал», ТОВ «УЗ Карго Вагон», ТОВ «Енерго Збут Транс», ПрАТ «СК «Таст-Гарантія») дозволить внутрішнім та зовнішнім користувачам інформації за допомогою фінансових i нефінансових показників та індикаторів отримати дані про стан інтелектуально-інноваційного розвитку залізничного транспорту як складного виробничо-технологічного комплексу, підвищити прозорість звітності, а керівництву АТ «Укрзалізниця» інтегрувати фінансову та інноваційно-інвестиційну стратегії розвитку компанії, збільшити рівень інформаційного забезпечення аналізу інвестиційно-інноваційної діяльності компанії.

Висновки. Таким чином, перспективи інноваційного розвитку залізничного транспорту безпосередньо пов'язані 3 ефективністю управління нематеріальними активами. Це вимагає збільшення якості облікової інформації, у першу чергу, в частині оприлюднення Консолідованого звіту про інтелектуальний капітал АТ «Укрзалізниця» та його дочірніх підприємств.

\section{СПИСОК ЛІТЕРАТУРИ}

1. Бондаренко С.А. Нематеріальні активи у забезпеченні інновачійного розвитку промислового підприємства // Глобальні та начіональні проблеми економіки. 2015. Вип. 4. С. 305-310.

2. Борисюк I.О. Формування системи управління інтелектуальною власністю авіаційних підприємств // Проблеми підвищення ефективності інфраструктури: Зб. наук. праџь. К.: НАУ, 2009. Bun. 23. C. 41-47.

3. Розвиток теоретико-методологічних засад обліку, аналізу, контролю $i$ аудиту: Монографія / За заг. ред. А.А. Пилипенка, Г.Ф. Азаренкова. Харків: ВД «ІНЖЕК», 2012. С. 73-94. 
4. Диба В. М. Обліково-аналітичне забезпечення управління нематеріальними активами: Монографія. К.: КНЕУ, 2015. 428 c.

5. Облікова концепиія управління вартістю нематеріальних активів підприсмства: Монографія / П.О. Кучик, І.М. Дрогобиџький, З.П. Плиса, X.I. Скоп. Львів: Растр-7, 2016. 268 c.

6. Старко I.С. Облік $i$ контроль нематеріальних активів у системі управління діяльністю підприємства: Автореф. дис. на здобуття наук. ступеня канд. екон. наук: 08.00.09; Центр. спілка спожсив. т-в Украӥни, Львів. комери. акад. - Львів, 2015. - 20 с.

7. Шелест В.С. Обліково-аналітичне забезпечення управління нематеріальними активами: Автореф. дис. на здобуття наук. ступеня канд. екон. наук: 08.00.09; ДВНЗ. К.: Нач. екон. ун-т ім. В. Гетьмана. К., 2014. $20 \mathrm{c}$.

8. Національне положення (стандарт) бухгалтерського обліку в державному секторі 122 «Нематеріальні активи» (із змінами, внесеними згідно з Наказами Міністерства фінансів № 1163 від 25.11.2014 № 664 від 23.07.2015). Режим достуny: https://zakon0. rada.gov. ua/ laws/ show/z1018-10/paran4\#n4

9. Положення (стандарт) бухгалтерського обліку 8 «Нематеріальні активи». URL: http://zakon4.rada.gov. ua/laws/show/z0750-99.

10. Міжнародний стандарт бухгалтерського обліку 38 «Нематеріальні активи». URL: http://zakon2.rada. gov.ua/laws/show/929_050.

11. Касс М.Е. Формирование стратегии инновачионного развития предприятия на основе управления нематериальными активами: Монография; Нижегор. гос. архитектур.-строит. ун-т. Н. Новгород: ННГАСУ, 2011. $159 \mathrm{c}$.

12. Семчик В. Формування майна Укрзалізниці: питання інтелектуальної власності // Теорія і практика інтелектуальної власності. 2018. Вип. 5. C. 57-62.

\section{REFERENCES}

1. Bondarenko, S.A. (2015). Nematerialni aktyvy u zabezpechenni innovatsiinoho rozvytku promyslovoho pidpryiemstva [Intangible assets in ensuring the innovative development of an industrial enterprise]. Hlobalni ta natsionalni problemy ekonomiky, Vip.4, 305-310 [in Ukrainian].

2. Borysiuk, I.O. (2009). Formuvannia systemy upravlinnia intelektualnoiu vlasnistiu aviatsiinykh pidpryiemstv [Formation of the intellectual property management system of aviation enterprises]. Problemy pidvyshchennia efektyvnosti infrastruktury. Kyiv: NAU,Vip. 23, 41-47 [in Ukrainian].

3. Pylypenka, A.A. (2012). Rozvytok teoretyko-metodolohichnykh zasad obliku, analizu, kontroliu $i$ audytu [Development of theoretical and methodological principles of accounting, analysis, control and audit]. Kharkiv: VD «INZhEK» [in Ukrainian].

4. Dyba, V. M. (2015). Oblikovo-analitychne zabezpechennia upravlinnia nematerialnymy aktyvamy [Accounting and analytical support for the management of intangible assets ]. Kyiv: KNEU, 428 [in Ukrainian].

5. Kutsyk, P. O. \& Drohobytskyi, I. M. (2016). Oblikova kontseptsiia upravlinnia vartistiu nematerialnykh aktyviv pidpryiemstva [Accounting 
concept of management of intangible assets of the enterprise]. - Lviv: Rastr. - 7, 268 [in Ukrainian].

6. Starko, I. Ye. (2015). Oblik i kontrol nematerialnykh aktyviv u systemi upravlinnia diialnistiu pidpryiemstva [Accounting and control of intangible assets in the enterprise activity management system]: avtoref. dis. ... kand. ekon. nauk, Lviv. 20 [in Ukrainian].

7. Shelest, V. S.(2014). Oblikovo-analitychne zabezpechennia upravlinnia nematerialnymy aktyvamy [Accounting and analytical support for the management of intangible assets]: avtoref. dis. ... kand. ekon. nauk, Kyiv, 20[in Ukrainian].

8. Natsionalne polozhennia (standart) bukhhalterskoho obliku $v$ derzhavnomu sektori 122 «Nematerialni aktyvy» (iz zminamy, vnesenymy zghidno z Nakazamy Ministerstva finansiv \# 1163 vid 25.11.2014 \# 664 vid 23.07.2015). Retrieved from: https://zakon0. rada.gov. ua/ laws/ show/z1018-10/paran4\#n4 [in Ukrainian].

9. Polozhennia (standart) bukhhalterskoho obliku 8 «Nematerialni aktyvy». Retrieved from http://zakon4.rada.gov. ua/laws/show/z0750-99.

10. Mizhnarodnyi standart bukhhalterskoho obliku 38 «Nematerialni aktyvy». Retrieved from http://zakon2.rada. gov.ua/laws/show/929_050.

11. Kass, M. E. (2011). Formirovanie strategii innovatsionnogo razvitiya predpriyatiya na osnove upravleniya nematerialnyimi aktivami [Formation of a strategy for innovative development of an enterprise based on intangible asset management]. N.Novgorod: NNGASU, 159 [in Russian].

12. Semchyk, V. (2018). Formuvannia maina Ukrzaliznytsi: pytannia intelektualnoi vlasnosti[Formation of Ukrzaliznytsya property: issues of intellectual property]. Teoriia i praktyka intelektualnoi vlasnosti, Vip.5, 57-62 [in Ukrainian].

Стаття надійшла до редакиії 16.08.2019

Посилання на статтю: Якименко-Терещенко Н. В., Жадан Т.А. Обліковоаналітичне забезпечення управління нематеріальними активами в контексті інноваційного розвитку залізничного транспорту // Розвиток методів управління та господарювання на транспорті: Зб. наук. праць, 2019. № 3. С. 86-96. DOI 10.31375/2226-1915-2019-3-86-96.

Received 16.08.2019

Reference a JournalArtic: Yakymenko-Tereschenko, N.V. \& Zhadan, T.A. (2019). Accounting and analytical software for non-tangible assets management in terms of railway transport innovative development. Development of management and entrepreneurship methods on transport, 86-96. DOI 10.31375/22261915-2019-3-86-96. 